\title{
SOIL AS A FACTOR INFLUENCING THE MANGROVE FOREST COMMUNITIES IN TALIDENDANG BESAR, RIAU
}

\author{
CECEPKUSMANA \\ Forest Ecology Laboratory, Department of Forest Management Faculty of \\ Forestry, Bogor Agricultural University, Bogor, Indonesia
}

\begin{abstract}
One transect of $10 \mathrm{~m} \times 900 \mathrm{~m}$ was constructed perpendicular to the sea edge to know the pattern of mangrove forest communities from the sea edge through the inland area. Then, one sample plot of $50 \mathrm{~m} \times 50 \mathrm{~m}$ was established at each forest community to explore its vegetation structure and soil characteristics.

The results show that in Talidendang Besar area, there are three mangrove forest communities stretching from the sea edge to the inland, namely Bruguiera parviflora, B. sexangula and B. sexangula-Nypa fruticans. The soil factors such as pH.EC (electrical conductivity), $\% \mathrm{~K}, \% \mathrm{Na}$, C-organic, $\mathrm{N}$-total, $\mathrm{NH}_{4}$ (ammonia), and CEC (cation exchange capacity) were regarded important in influencing the pattern of the mangrove forest communities.
\end{abstract}

\section{INTRODUCTION}

Darsidi (1987) reported that the mangrove forest in Indonesia covers an area of approximately 4.25 million ha, of which about 276000 ha are distributed in Riau. Most of the mangrove forests in Riau are located at the east coast where the major tidal swamp land areas are under development for transmigration projects.

Numerous environmental factors operate in mangrove swamps, but the most important are soil type, salinity, drainage, and water currents (Chapman 1975). Steenis (1958) stated that the soil type is more important than the other factors in controlling the zonation of mangroves. In any area with fairly uniform climate, the chemical differences in the soil may produce marked changes in the vegetation (Billing 1950).

While the mangrove forest in Indonesia is believed to be the largest in the world (Christensen 1982), studies on the physico-chemical properties of mangrove soils are still few (Soegiarto 1979).

The present study was done to investigate the soil factors influencing the mangrove forest communities in Talidendang Besar, Riau. It is hoped that the results of this research may contribute to the establishment of proper mangrove forest management in Indonesia. 


\section{MATERIALS AND METHODS}

This research was conducted in a mangrove forest concession area at Tali-dendang Besar belonging to the PT Bina Lestari which is located in the Kateman District, Indragiri Hilir Regency, Riau Province. Geographically, this mangrove forest area is located at the east coast of Sumatera with gentle topography and altitude of $0-3 \mathrm{~m}$ above sea level between Long. $103^{\circ} 28^{\prime}$ to $103^{\circ} 48^{\prime} \mathrm{E}$ and Lat. $0^{\circ} 21^{\prime}$ to $1^{\circ} \mathrm{N}$ (Figure 1). Based on the systems of Schmidt and Ferguson (1951), the Tem-

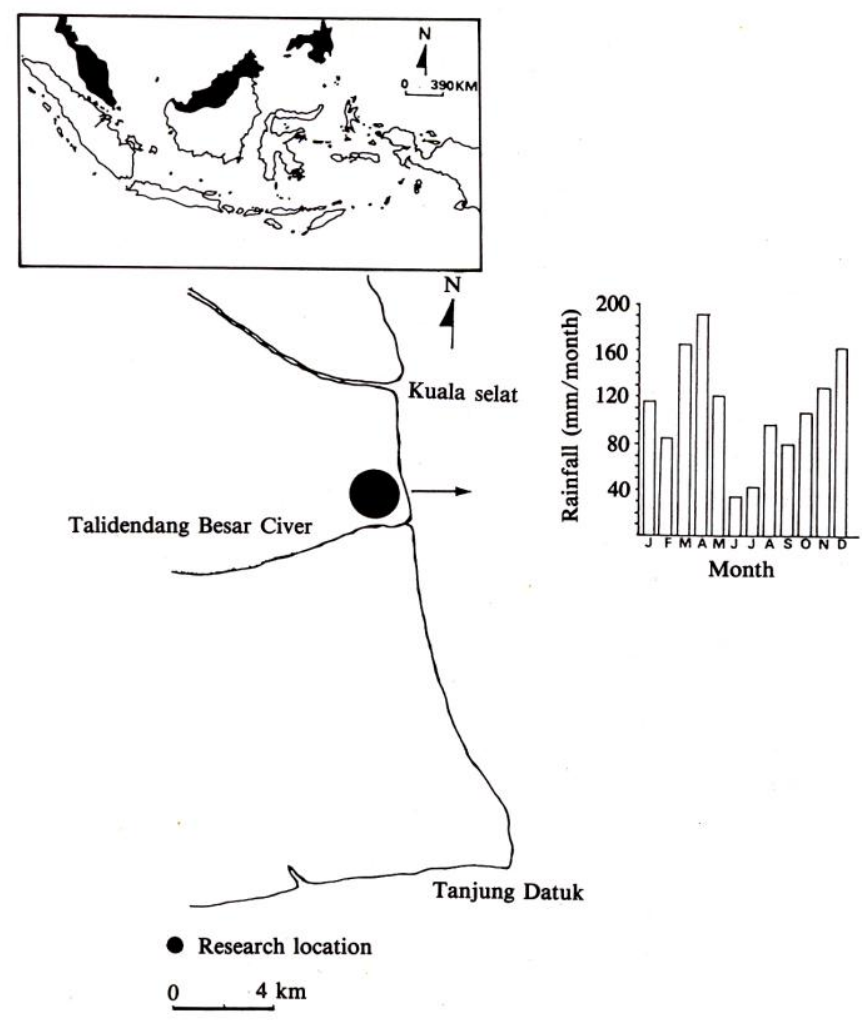

Figure 1. Location and the climatic diagram ofthe mangrove forest area of Talidendang Besar, Riau. 
bilahan research area has a B climate type with seven wet months, two dry months, and three humid months (Badan Meteorologi dan Geofisika 1990). The soils of this area are organosol and glei humus (Lembaga Penelitian Tanah 1964).

To investigate the forest community from the sea edge to the inland, one transect of 10 $\mathrm{m} \times 900 \mathrm{~m}$ was divided into $10 \mathrm{~m}$ x $20 \mathrm{~m}$ contiguous subplots and constructed perpendicular to the sea edge. Within these subplots, the DBH (diameter at breast-height) of all trees (plants with DBH $10 \mathrm{~cm}$ up) was measured. Then, one sample plot of $50 \mathrm{~m} \mathrm{x}$ $50 \mathrm{~m}$ was established in each forest community type to explore its vegetation structure and soil characteristics. Four soil samples up to a depth of $25 \mathrm{~cm}$ were collected randomly from the area within each adjacent sample plot of $50 \mathrm{~m}$ x $50 \mathrm{~m}$. Each soil sample was analysed for texture, $\mathrm{pH}, \mathrm{C}$-organic, EC (electrical conductivity), CEC (cation exchange capacity), N-total, NH4 (ammonia), and exchangeable cations (K, Na, Mg, Ca) at the soil laboratory of the Faculty of Agriculture, Bogor Agricultural University.

The vegetation data were analysed using Cox's method (1967) and the importance value index (Curtis and Mclntosh 1951) was used to determine the vegetational importance of a species within the forest community.

\section{RESULTS AND DISCUSSION}

\section{A. Vegetation Composition}

As shown in Figure 2, the mangrove forest from the sea edge to the inland in Talidendang Besar could be divided into three different forest communities, namely, Bruguiera parviflora community which occupied the area from the sea edge to about 180 $\mathrm{m}$ inland, B. sexangula community from about $180 \mathrm{~m}$ to $740 \mathrm{~m}$ inland, and $B$. sexangula- $N$. fruticans community from about $740 \mathrm{~m}$ to $900 \mathrm{~m}$ inland as transition area with swamp forest.

Table 1 shows that in the $B$. parviflora community, $B$. parviflora was considered the dominant species and $B$. sexangula the codominant one. In the $B$. sexangula community, B. sexangula was considered the dominant species and B. parviflora the codominant one, while in the $B$. sexangula- $N$. fruticans community, B. sexangula was dominant and TV. fruticans codominant.

There is a marked tendency for the density and basal area of B. parviflora to decrease from the sea edge (B. parviflora community) to the inland (B. sexangula- $N$. fruticans community). The opposite occurred for the density and basal area of $B$. sexangula which tended to increase toward the inland area. In addition, the further from the sea edge, the more varied was the tree species richness. It is assumed that the less severe site conditions in the inland area give the chance to 
BIOTROPIA No. 4, 1990/1991

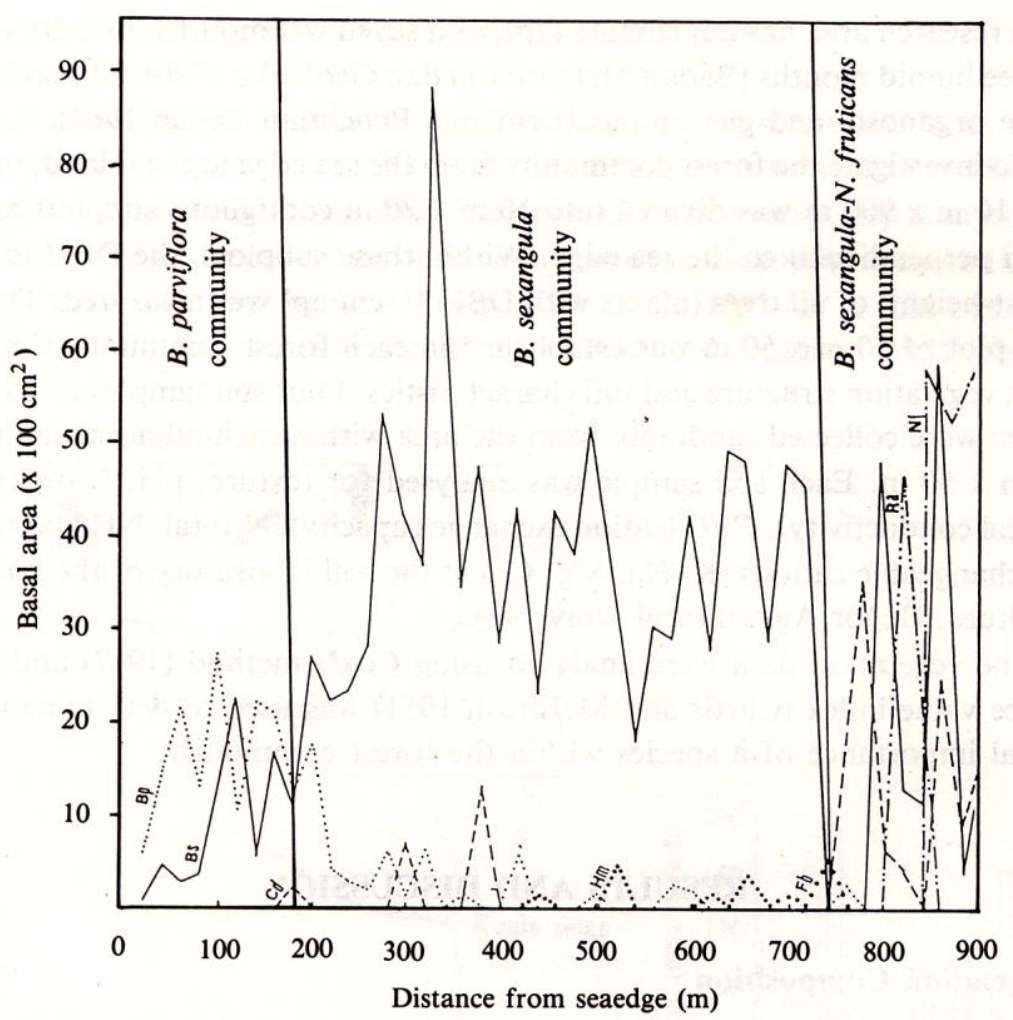

Figure 2. Mangrove forest community from sea edge through inland in mangrove forest area of Talidendang Besar, Riau. Bp (B. parviflora), Bs (B. sexangula), Cd (C. decandra), Hm (//. microcarpum), $\mathrm{Fb}$ (F. benjamina), Ra (R. apiculata), and Nf (TV. fruticans).

Table 1. Species density and species importance value index (IVI) of trees at three forest communities in a mangrove forest of Talidendang Besar, Riau

\begin{tabular}{llcc}
\hline \hline Community type & Species & $\begin{array}{l}\text { Density } \\
\text { (in./ha) }\end{array}$ & IVI \\
\hline 1. B. parviflora & B. parviflora & 392 & 171.95 \\
community & B. sexangula & 200 & 128.05 \\
\hline 2. B. sexangula & B. parviflora & 164 & 100.12 \\
community & B. sexangula & 300 & 199.89 \\
\hline 3. B. sexangula & B. parviflora & 8 & 8.33 \\
N. fruticans & B. sexangula & 340 & 199.93 \\
community & R. apiculata & 16 & 22.26 \\
& F. benjamina & 4 & 4.17 \\
& N. fruticana & 56 & 65.31 \\
\hline
\end{tabular}


Soil as a factor influencing the mangrove forest communities-C. Kusmana

many species for a better growth. Johnstone (1983) stated that the presence of terrestrial species in the back zone of mangal is more indicative of the salinity regime than representing an active process of colonization from the land as part of an integrated successional system.

\section{B. Forest Community Occurrence as Related to Soil Factors}

As shown in Table 2, the soils which occupied each forest community have a high percentage of clay, an intermediate percentage of silt, and a low percentage of sand. This indicates that the mangrove forest area in Talidendang Besar receives much eroded soil containing fine soil particles through the stream flow from the upper river basin of Talidendang Besar. It is probably due to the extensive conversion of peat swamp forest to coconut plantation mainly by the Bugis people who came from the southern part of Sulawesi. The soils covered either by B. parviflora or B. sexangula communities were classified as clay, while the soils covered by $B$. sexangula- $N$. fruticans were classified as silty clay. The soils of this mangrove forest area were almost the same as those of the mangrove forest area in Ujung Karawang, Cilacap (Al Rasyid 1971; Soerianegara 1971), and Bengkalis (Dinas Kehutanan Propinsi Dati I Riau 1978).

The $\mathrm{pH}$ of the soils which covered each of the forest community was generally neutral due to the decreasing percentage of exchangeable cation content in the soils from the sea edge of the inland area. Similarly the salinity (electrical conductivity) of the soils tends to decrease toward the inland, but generally the salinity of the soils occupied by each forest community was considered low, and the adsorption site of the soils was dominated by cations in the order of $\mathrm{Ca}>\mathrm{Mg}>\mathrm{Na}>\mathrm{K}$. This is suggested to be due to the fact that the mangrove forest in this area receives much fresh water through the stream flow of Talidendang Besar river, while the area toward inland was infrequently submerged by sea water.

C-organic, $\mathrm{NH}_{4}$ (ammonia), N-total, and $\mathrm{CEC}$ (cation exchange capacity) increased toward inland. It indicates that toward the inland area the organic matter and its decomposition process tends to increase. It is probably correlated with the maturity of the trees and the soil substrate condition in these forest communities. Based on the average height and diameter of the trees in these forest communities (Table 1), the inland area of the forest community appears to be occupied by more mature trees as suggested by the amount of litter fall on the forest floor. In addition, the dense aerial roots and the Acrostichum aureum on the floor of the B. sexangula and B. sexangula- $N$. fruticans communities play an important role in trapping leaves and debris during tidal inundation, thereby contributing to the high organic matter content in these forest communities. The increasing content of $\mathrm{N}$ and $\mathrm{NH}_{4}$ of the soil covered by the forest community toward inland indicated a more rapid decom- 
BIOTROPIA No. 4, 1990/1991

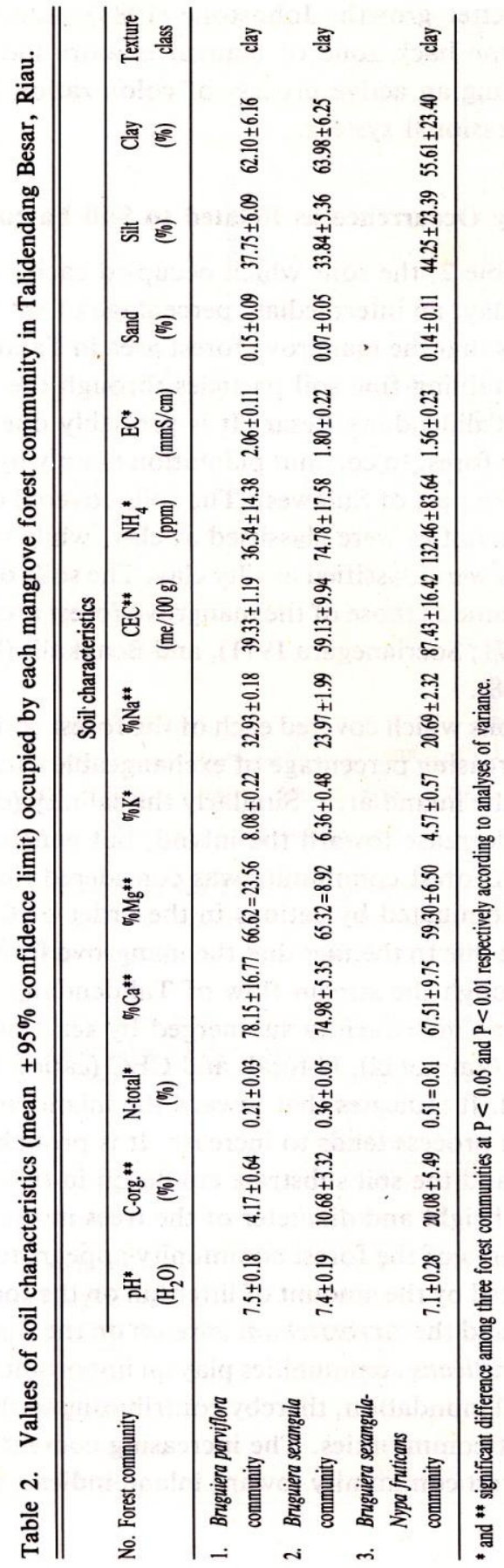


position process of organic matter on sites further from the sea edge. It is probably due to the decreasing frequency of inundation of the sites toward inland so that the soils are rather stable and more or less well-drained. Ponnamperuma (1972) stated that the accumulation of ammonia in anaerobic soils is due to the lack of oxygen to carry the oxidation from nitrite to nitrate, and so the mineralization of organic nitrogen in these soils stop at the ammonia stage. Furthermore, Broto (1984) reported that if anaerobic soil has a $\mathrm{pH}$ greater than 7.0 ammonia volatilization might take place through a denitrification process resulting in severe losses of nitrogen from the soils.

There was a significant difference among the three forest communities for eight soil characteristics such as $\mathrm{pH}, \mathrm{C}$-organic, $\mathrm{N}$-total, \% $\mathrm{K}, \% \mathrm{Na}, \mathrm{NH}_{4}, \mathrm{CEC}$, and EC (Table 2). These soil characteristics appeared to be important in influencing the occurrence pattern of mangrove forest communities in Talidendang Besar. Based on a statistical test using least significant difference (Table 3), the values of C-organic, CEC, EC, \% K, and $\% \mathrm{Na}$ were significantly different between forest communities, but the contents of $\mathrm{N}$ and $\mathrm{NH}_{4}$ were only significantly different between the B. parviflora and B. sexangula-N. fruticans communities. Meanwhile, the $\mathrm{pH}$ of the soils was significantly different among the three forest communities, except between the B. parviflora and B. sexangula community. If the three mangrove forest communities were ranked according to their relative positions with regard to these important soil characteristics (Table 4), the $B$. parviflora community tends

Table 3. Least significant difference (LSD) test for soil characteristics showing significant difference among three forest communities

\begin{tabular}{llccc}
\hline \hline \multirow{2}{*}{ No. } & \multirow{2}{*}{ Soil characteristics } & \multicolumn{3}{c}{ Community type } \\
\cline { 3 - 5 } & & 1 vs 2 & 1 vs 3 & 2 vs 3 \\
\hline 1. & $\mathrm{PH}$ & $\mathrm{ns}$ & $* *$ & $*$ \\
2. & $\mathrm{C}-$ organic & $* *$ & $* *$ & $* *$ \\
3. & $\mathrm{~N}-$ total & $\mathrm{ns}$ & $*$ & $\mathrm{~ns}$ \\
4. & $\mathrm{NH}_{4}$ & $\mathrm{~ns}$ & $*$ & ns \\
5. & $\% \mathrm{~K}$ & $* *$ & $* *$ & $* *$ \\
6. & $\% \mathrm{Na}$ & $* *$ & $* *$ & $* *$ \\
7. & $\mathrm{CEC}$ & $* *$ & $* *$ & $*$ \\
8. & $\mathrm{EC}$ & $*$ & $* *$ & \\
\hline
\end{tabular}

- Community type 1: Bruguiera parviflora community

- Community type 2: Bruguiera sexangula community

-Community type 3: Bruguiera sexangula-Nypa fruticans community

* significant difference at $\mathrm{P}<0.05$

$* *$ significant difference at $\mathrm{P}<0.01$

ns non-significant. 
Table 4. Relative position of three forest communities ranked according to mean values of eight important soil characteristics

\begin{tabular}{lllllllll}
\hline \hline \multirow{2}{*}{ Rank } & \multicolumn{7}{c}{ Soil characteristics } \\
\cline { 2 - 9 } & $\mathrm{pH}$ & C-org. & N-total & $*_{\mathrm{K}}$ & $\% \mathrm{Na}$ & $\mathrm{CEC}$ & $\mathrm{NH}_{4}$ & $\mathrm{EC}$ \\
\hline 1 & $\mathrm{BP}$ & Bs-Nf & Bs-Nf & $\mathrm{Bp}$ & $\mathrm{Bp}$ & $\mathrm{Bs}-\mathrm{Nf}$ & $\mathrm{Bs}-\mathrm{Nf}$ & $\mathrm{Bp}$ \\
2 & $\mathrm{Bs}$ & $\mathrm{Bs}$ & $\mathrm{Bs}$ & $\mathrm{Bs}$ & $\mathrm{Bs}$ & $\mathrm{Bs}$ & $\mathrm{Bs}$ & $\mathrm{Bs}$ \\
3 & Bs-Nf & Bp & Bp & Bs-Nf & Bs-Nf & $\mathrm{Bp}$ & $\mathrm{Bp}$ & Bs-Nf \\
\hline
\end{tabular}

\begin{tabular}{ll}
\hline $\mathrm{Bp}$ & : Bruguiera parviflora community \\
$\mathrm{Bs}$ & : Bruguiera sexangula community \\
$\mathrm{Bs}-\mathrm{Nf}$ & : Bruguiera sexangula-Nypa fruticans community.
\end{tabular}

to occupy soils which contain higher $\% \mathrm{Na}, \% \mathrm{~K}, \mathrm{EC}$ and $\mathrm{pH}$, and lower C-organic, $\mathrm{N}$-total, $\mathrm{NH}_{4}$, and CEC compared to the others. On the contrary, the soils occupied by the $B$. sexangula- $N$. fruticans community contained lower $\% \mathrm{Na}, \% \mathrm{~K}, \mathrm{EC}$ and $\mathrm{pH}$, and higher C-organic, $\mathrm{N}$ - total, $\mathrm{NH}_{4}$, and CEC. The $B$. sexangula community tends to occupy soils which contain intermediate values of these soil characteristics. It means that in Talidendang Besar, B. parviflora tends to grow on the rather saline and soft mud clayey soils in the area near the sea edge which is frequently submerged in sea water. $B$. sexangula can grow on various types of mud ranging from rather soft clayey soils in the area near the sea edge to the hard silty clayey soils in the inland area which is infrequently submerged in sea water. $B$. sexangula tends to grow optimally on rather hard silty clayey soil with $\mathrm{pH} 7.0$ in the inland area, while the other species viz N. fruticans and Ficus benjamina occur in the innermost zone of the mangrove with lower salinity. Yamaha and Sukardjo (1979) reported that in South Sumatera, B. parviflora grows in soft mud, while B. sexangula grows mixed with $B$. gymnorrhiza and Rhizophora apiculata in the innermost zone of mangroves on rather hard mud soil.

\section{CONCLUSIONS}

The mangrove forest in Talidendang Besar could be divided into Bruguiera parviflora community occupying an area from the sea edge to about $180 \mathrm{~m}$ inland, $B$. sexangula community from about $180 \mathrm{~m}$ to $740 \mathrm{~m}$ inland, and $B$. sexangula- $N$. fruticans community from about $740 \mathrm{~m}$ to $900 \mathrm{~m}$ inland. In the $B$. parviflora community, $B$. parviflora was considered the dominant species and $B$, sexangula the codominant one. In the $B$. sexangula community, $B$. sexangula was considered the dominant species and $B$. parviflora the codominant one, while in the B. sexangula- 
Soil as a factor influencing the mangrove forest communities - C. Kusmana

N. fruticans community, B. sexangula was considered the dominant species and TV. fruticans the codominant one.

There were eight soil characteristics considered important in influencing the occurrence pattern of the mangrove forest community in Talidendang Besar, Riau: $\mathrm{pH}$, EC (electrical conductivity), CEC (cation exchange capacity), C-organic, N-total, $\mathrm{NH}_{4}, \% \mathrm{~K}$, and \% Na.

\section{REFERENCES}

AL RASYID, H. 1971. Pemilihan jenis tanaman dalam rangka meningkatkan produksi hutan payau Ujung Karawang. Laporan No. 134, Lembaga Penelitian Hutan, Bogor.

BADAN MEIEOROLOGI DAN GEOFISIKA. 1990. Keadaan curah hujan di Propinsi Riau. Departemen Perhubungan Republik Indonesia. Badan Meteorologi dan Geofisika, Jakarta.

BLLINGS, W.D. 1950. Vegetation and plant growth as affected by chemically altered rocks in the westem Great Basin. Ecology 31: 62-74.

BROTO, K.G. 1984. Waterlogged saline soils. In: Snedaker, S.C. and J.G. Snedaker (Eds.). The mangrove ecosystem: research methods: 114-130. UNESCO, Paris.

CHAPMAN, V.J. 1975. Mangrove vegetation. Strauss and Cramer GmbH, Germany. 499 p.

CHRISTENSEN, B. 1982. Management and utilization of mangroves in Asia and the Pacific. FAO Environment Paper 3. FAO, Rome.

Cox, G.W. 1967. Laboratory manual of general ecology. Brown Company Publishers, Dubuque, Iowa. 195 p.

CURTIS, J.T. and R.P. MCINTOSH. 1951. An upland forest continuum in the prairie-forest border region of Wisconsin. Ecology 32 (3): 476-496.

DARSIDI, A. 1984. Pengelolaan hutan mangrove di Indonesia. In: Soemodihardjo, Soerianegara, Sutisna, Kartawinata, Supardi, Naamin, and Al Rasyid (Eds.). Presiding Seminar II Ekosistem Mangrove, Baturaden 3-5 Agustus 1982: 19-28. MAB-LIPI, Jakarta.

DINAS KEHUTANAN PROPINSI DATI I RiaU. 1979. Hutan mangrove di Propinsi Riau. In: Soemodihardjo, Nontji, dan Djamali (Eds.). Presiding Seminar Ekosistem Hutan Mangrove, Jakarta 27 Pebruari -1 Maret 1978: 176-185. MAB-LIPI, Jakarta.

LEMBAGa PeneltTian tanAh. 1964. Peta tanah eksplorasi Sumatera bagian selatan, skala 1:1 000 000. Departemen Pertanian Republik Indonesia, Lembaga Penelitian Tanah, Bogor.

JOHNSTONE, I.M. 1983. Succession in zoned mangrove communities: Where is the climax? In: Teas, H.J. (Ed.). Biology and ecology of mangroves: 131-139. W. Junk Publishers, The Hague.

PONNAMPERUMA, F.N. 1972. The chemistry of submerged soils. Advances in Agronomy 24: 29-96.

SCHMIDT, F.H. and J.H.A.FERGUSON. 1951. Rainfall type based on wet and dry period ratios of Indonesia with western New Guinea. Verhandelingen No. 42, Kementerian Perhubungan Djawatan Meteorologi dan geofisik, Jakarta.

SOEGIARTO, A. 1979. The mangrove ecosystem in Indonesia, its problems and management. Paper prepared for the Second International Symposium on Biology and Management of Mangrove, July 20-26, 1980, Port Moresby, Papua New Guinea. 


\section{BIOTROPIA No. 4, 1990/1991}

SOERIANEOARA, I. 1971. Characteristics and classification of mangrove soils of Java. Rimba Indonesia 16 (3,4): 141-150.

STEENIS, C.G.G.J. van. 1958. Ecology (The introductory part to the monograph of Rhizophoraceae by Ding Hou). Flora Mal. 5: 431-441.

YAMADA, I. and S. SUKARDJO. 1979. Ecological study of mangrove and swamp forest in South Sumatera, J. Southeast Asian Studies 17 (3): 425-443. 